\title{
Relationship between clinical and postmortem evaluation in repeat breeder beef cows
}

\author{
Relação entre características clínicas e post-mortem em vacas de corte repetidoras de serviço
}

\author{
Rogério Ferreira ${ }^{I}$ João Francisco Coelho de Oliveira' ${ }^{I I}$ Alfredo Quites Antoniazzi ${ }^{I}$ \\ Cláudio Alves Pimentel ${ }^{\mathrm{III}}$ José Carlos Ferrugem Moraes ${ }^{\mathrm{IV}}$ Luiz Ernani Henkes $^{\mathrm{V}}$ \\ Vilceu Bordignon ${ }^{\mathrm{VI}}$ Paulo Bayard Dias Gonçalves ${ }^{* I I}$
}

\begin{abstract}
The objective of this study was to investigate the causes of the repeat breeder syndrome comparing clinical signs and postmortem findings in beef cows. The identification of factors affecting the reproductive tract can support decisions as to whether treatment of repeat breeder cows is justifiable than culling. Since all animals were submitted to clinical examination before being slaughtered, this study has a differential approach when compared with others, where genital tracts from abattoir were examined. In this study, 130 crossbred cows and heifers that have failed to conceive after three or more services were identified, submitted to a clinical examination and blood collection for karyotyping and sent to an abattoir. Postmortem examinations included macroscopic evaluation of the genital tracts, bacteriology and histopathology of the uterus. Uterine alterations were predominant followed by oviduct and ovarian pathologies. Histopathological examination was more sensitive as a diagnostic tool than clinical examination. Repeat breeder cows had a predominance of uterine abnormalities (95\%), such as inflammatory (42.9\%) and degenerative (59.7\%) conditions. Oviduct abnormalities were found in $29.8 \%$ of animals. Furthermore, 1 out 10 karyotyped cows showed aneuploidy. Thus, this study stressed the importance of laboratory exams in the diagnosis of the causes of infertility of repeat breeder cows.
\end{abstract}

Key words: repeat breeder, beef cows, cattle, infertility, theriogenology.

\section{RESUMO}

O objetivo deste estudo foi avaliar as causas de infertilidade em vacas de corte repetidoras de serviço, relacionando sinais clínicos com características laboratoriais post-mortem. A identificação dos fatores que afetam o desempenho reprodutivo pode fornecer uma fundamentação científica para auxiliar na decisão quanto ao destino de vacas repetidoras de serviço; tratamento ou descarte. Este estudo tem abordagem diferencial dos trabalhos que contemplam somente a ocorrência de alterações post-mortem do trato genital. A correlação das alterações post-mortem com o histórico clínico dos animais pode auxiliar na determinação da causa de repetição de serviço de animais sem alteração clínica. Foram utilizadas 130 vacas e novilhas cruzas que não conceberam depois de, no mínimo, três serviços. Todos os animais foram identificados $e$ submetidos à exame clínico e coleta de sangue para cariotipagem. Foram incluídos no estudo apenas animais com histórico de falha reprodutiva. Os animais foram encaminhados para um abatedouro e foram realizados exames post-mortem como inspeção macroscópica do trato genital, cultura bacteriológica e estudo histopatológico do útero. Alterações uterinas foram predominantes seguidas de alterações de oviduto e ovário. Foi observada uma maior freqüência de alterações histopatológicas de útero que alterações clínicas. Os animais utilizados no estudo apresentaram alta freqüência de patologia uterina (95\%), tanto inflamatórias (42,9\%) quanto degenerativas (59,7\%). Patologias diagnosticadas somente por exames post-mortem e laboratoriais como oclusão tubária $(29,8 \%)$ e trissomia do par sexual também foram observadas (1/10 vacas). Portanto, este estudo evidencia a importância do exame laboratorial no diagnóstico das causas de infertilidade de vacas com histórico de repetição de serviço.

Palavras-chave: vacas repetidoras de serviço, vacas de corte, bovinos, infertilidade, ginecologia.

\footnotetext{
IPrograma de Pós-graduação em Medicina Veterinária, Universidade Federal de Santa Maria (UFSM), Santa Maria, RS, Brasil.

${ }^{I I}$ Departamento de Clínica de Grandes Animais, UFSM, Hospital Veterinário, 97105-900, Santa Maria, RS, Brasil. E-mail: bayard@biorep.ufsm.br.*Autor para correspondência.

IIIDepartamento de Patologia, Universidade Federal de Pelotas, Pelotas, RS, Brasil.

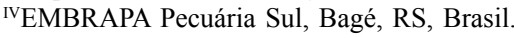

vAnimal Reproduction and Biotechnology Laboratory, Colorado State University, Fort Collins, Colorado, USA.

${ }^{\mathrm{VI} D e p a r t m e n t}$ of Animal Science, McGill University, Montreal, Quebec, Canadá.
} 


\section{INTRODUCTION}

According to SHORT et al. (1990), anestrus is the main component of postpartum infertility in beef cattle production systems and can be related to deficient management associated with low feed levels during breeding seasons and the suckling stimulus. Another factor causing an economic loss in the bovine production systems is the presence of repeat breeder cows (ZEMJANIS, 1980; BARTLETT et al., 1986; BAGE et al., 1997). According to the definition proposed by ZEMJANIS (1980), a repeat breeder cow is any cow that have failed to conceive after three or more services, showing normal estrous cycles and no clinical pathologies.

In repeat breeder beef cows, the cause for infertility might be either fertilization failure or early embryonic death. The etiology may involve a combination of many factors, like management and nutritional disorders, physiological conditions, infections, disturbed hormonal interplay, and genetic factors (HANLY, 1961; AYALON, 1978; LAMMING \& DARWASH, 1998; BAGE et al., 2002). Besides, there are only a few detailed investigations on repeat breeding causes relating clinical and postmortem evaluation in beef cattle (WILLIAMS et al., 2005). In addition, most of the studies identifying fertility problems are not always related to a specific clinical sign (KATAGIRI \& TAKAHASHI, 2004; GIVENS, 2006).

The identification of animals with reproductive problems can help reduce beef cattle production costs. An attempt to identify repeat breeder cows is usually done by clinical exam. Our hypothesis is that repeat breeder cows may have microscopic disorders on their reproductive tract not clinically detectable by ordinary exams. The identification of factors affecting reproductive performance can provide scientific support to decide on treating or culling repeat breeder cows in order to increase reproductive efficiency in beef cattle. The objective of this study was to investigate repeat breeding causes relating clinical signs and postmortem laboratory characteristics in beef cattle.

\section{MATERIAL AND METHODS}

Animals

A total of 130 crossbred Hereford vs. Nelore cows and heifers from 7 farms $\left(54.10^{\circ} \mathrm{W} ; 31.33^{\circ} \mathrm{S}\right)$ that failed to conceive after at least three artificial inseminations and natural breeding with tested bulls were examined. These animals were from herds, which were cycling and had a conception and pregnancy rate around $70 \%$ after one artificial insemination. All animals were properly identified, had blood drawn for karyotyping and were submitted to a gynecological examination following the protocol proposed by GRUNERT \& GREGORY (1984). The ovaries were classified by size and by the presence of ovarian structures such as follicles, corpora lutea and abnormalities. The uterus was classified based on size, tonus and presence or absence of discharge (NEVES, 1976). The vulva and vagina were visually examined and classified as normal or abnormal (NEVES, 1976).

\section{Postmortem genital tract evaluation}

Immediately after slaughter, the genital tract was taken to the laboratory for a detailed macroscopic evaluation. The oviductal patency assessment was carried out through a perfusion of $0.9 \%$ sodium chloride solution with $1 \%$ Methylene Blue. The oviduct was classified and ranked according to its patency (patent; partially patent; occluded). During ovarian macroscopic evaluation, the presence of large follicle $(>10 \mathrm{~mm})$ or corpus luteum served as an indicator of its functionality.

\section{Bacteriological exam}

Samples for bacteriology were collected from the uterine lumen using sterilized cotton swab sticks. Bacteria were cultured in blood agar, MacConkey agar and simple medium. After incubation at $37^{\circ} \mathrm{C}$ for 24 to 48h (JANG et al., 1976), bacteria were identified based on the colony characteristics, Gram staining, morphology, hemolysis, and biochemical profile (WILLIAMS et al., 2005).

\section{Histopathological exam}

Histopathology samples were collected from a middle portion of the right uterine horn and fixed in Bouin (LUNA, 1968) for 48h, transferred to 70\% ethanol and taken to a histopathology laboratory to be processed according to LUNA (1968). The fixed uterine fragments were dehydrated, bleached, embedded in paraffin wax, cut in $5 \mu \mathrm{m}$ slices and stained with hematoxilin-eosin for light microscopy examination. The histopathological findings were classified according to the presence and severity of inflammatory and degenerations conditions (STUDER \& MORROW, 1978).

\section{Karyotyping}

Blood samples were collected from the jugular vein of 10 animals, using heparinized syringes. The samples were kept at 5 to $10^{\circ} \mathrm{C}$ and transported to 
the laboratory within 24h. Lymphocytes (four drops of blood) were cultured in $10 \mathrm{~mL}$ of karyotyping medium containing phytohaemagglutinin (PHA) for $72 \mathrm{~h}$ at $39^{\circ} \mathrm{C}$, with gentle shaking, for a few seconds, every $12 \mathrm{~h}$. After $70 \mathrm{~h}$ of incubation, $50 \mu \mathrm{L}$ of colchicine solution $(0.025 \%$, $\mathrm{w} / \mathrm{v}$ ) was added to the lymphocyte culture. At the end of incubation $(72 \mathrm{~h}$ ), cultures were centrifuged at $144 \mathrm{x}$ $\mathrm{g}$ for $5 \mathrm{~min}$ to separate the supernatants and $4 \mathrm{~mL}$ of $75 \mathrm{mM}$ potassium chloride was added to the pelleted cells to produce hypotonicity. The mixture was allowed to stand for $15 \mathrm{~min}$ before adding $4 \mathrm{~mL}$ of Carnoy's fluid [3:1 (v/v) methanol/acetic acid] fixative, allowing the cells to be fixed for $24 \mathrm{~h}$. Posteriorly, the mixture was centrifuged and washed three times with the same volume of Carnoy fixative. Slides were prepared by placing a few drops of the fixed material on cold microscope slides, which were then flamed and stained with Giemsa and examined by clear-field microscopy at 1000X magnification. Metaphase were counted and examined, and the total number of chromosome was counted.

\section{Statistical analyses}

The presence of alterations in different parameters was compared by a non-parametric method using a category model data procedure (PROC CATMOD) of the Statistical Analysis System package (SAS). The relation between the degree of uterine inflammation and cervix size was analyzed by a general linear model procedure (PROC GLM) of SAS.

\section{RESULTS AND DISCUSSION}

In the present study, all animals were subjected to a clinical evaluation and the findings compared with the results of a postmortem examination. This is a different approach when compared with those studies where only genital tracts from abattoir were used to study the repeat breeder cow syndrome (MARTINS et al., 2002). The combination of clinical, laboratorial and postmortem examination helped us to determine the specific etiology of repeat breeders. These information provide new insights to help the diagnosis and decisions as to whether treatment of repeat breeder cows is justifiable than culling. Hormonal disturbs and ovulation failures are important infertility causes however, they were not approached in this study. Results from clinical and postmortem exams are shown on tables 1 and 2. The difference in numbers between clinical and postmortem examination were due to technical reasons beyond our control.

On figure 1, data were analyzed aiming to identify the organ responsible for most subfertility condition of repeat breeders. Postmortem macroscopic and laboratory results based on uterine, ovarian and oviductal examination were analyzed. Uterine alterations were predominant $(\mathrm{P}<0.0001)$ followed by ovarian and oviductal pathologies $(\mathrm{P}<0.01)$. The uterus is the genital organ more susceptible to alterations due to its anatomic, functional and histological characteristics (ROBERTS, 1986). It is accepted that uterine infections play an important role in the reproductive failures in the cow (ZEMJANIS, 1980). However, it has been argued that endometritis may not play such an important role in beef cattle fertility (ROBERTS, 1986).

In the present study, we showed that almost $50 \%$ of the repeat breeder cows had some degree of uterine inflammatory reaction and we found a good agreement between clinical (34.6\%) and histopathology $(42.9 \%)$ results. Both findings pointing for a high incidence of uterine inflammatory processes in repeat breeder beef cows. Interestingly, we observed some animals showing uterine histopathology alterations without signs of bacterial contamination. A relationship between clinical and bacteriological exams was not observed by NEVES (1976) who also noted bacterial growth in healthy animals with no clinical alterations. This suggests the possibility of recrudescence infections with endometrial histopathology damage that could affect the fertility. Furthermore, histopathological examination detected a higher prevalence of uterine infection than clinical exams $(\mathrm{P}<0.0001)$. This discrepancy is not a surprise, since uterine clinical evaluation was based only by cervix size and vaginoscopy. Besides, there was no correlation between cervix diameter and the presence of endometrial inflammation ( $\mathrm{P}>0.05$; data not shown),

Table 1 - Clinical alterations found in different organs of the reproductive tract in repeat breeder beef cows.

\begin{tabular}{lcccccc}
\hline Status & Uterus & Oviduct & Ovarian structures & Ovary & Vulva & Vagina \\
\hline Absence* & $85(65.4 \%)$ & $130(100 \%)$ & $7(5.7 \%)$ & $127(97.7 \%)$ & $128(98.5 \%)$ & $128(98.5 \%)$ \\
Presence* & $45(34.6 \%)$ & 0 & $117(94.4 \%)$ & $3(2.3 \%)$ & $2(1.5 \%)$ & $2(1.5 \%)$ \\
Ttotal & 130 & 130 & 124 & 130 & 130 & 130 \\
\hline
\end{tabular}

*Clinical signs/abnormalities/ovarian structures. 
Table 2 - Postmortem alterations found in different organs of the reproductive tract in repeat breeder beef cows.

\begin{tabular}{|c|c|c|c|c|c|c|}
\hline \multirow{3}{*}{ Status } & \multirow{3}{*}{ Bacterial } & \multirow{2}{*}{\multicolumn{3}{|c|}{ - }} & \multirow{3}{*}{$\begin{array}{l}\text { Inspection } \\
\text { Normal. }\end{array}$} & \multirow{3}{*}{$\begin{array}{c}\text { Ovary } \\
\text { Inspection } \\
\text { Structures } \\
\end{array}$} \\
\hline & & & & & & \\
\hline & & Inflammation & Fibrosis & Adenomyosis & & \\
\hline Absence* & $44(68.8 \%)$ & $44(57.1 \%)$ & $31(40.3 \%)$ & $41(53.3 \%)$ & $63(98.4 \%)$ & $3(5.4 \%)$ \\
\hline Presence* & $20(31.3 \%)$ & $33(42.9 \%)$ & $46(59.7 \%)$ & $36(46.8 \%)$ & $1(1.6 \%)$ & $53(94.6 \%)$ \\
\hline Total & 64 & 77 & 77 & 77 & 64 & 56 \\
\hline
\end{tabular}

*Postmortem macroscopic/microscopic/bacteriological characteristics.

indicating that cervix diameter is not a reliable parameter to evaluate endometrial status. The estrous cycle phase can compromise the detection of uterine discharges since the cervix is open during estrus and closed during diestrus. Furthermore, uterine changes through the estrous cycle, mainly those caused by estradiol, stimulate natural immunity against uterine infections (ROBERTS, 1986). Besides that, this study leads us to believe that several degrees of uterine inflammation and infections are present in cycling beef cows. Together, these findings suggest that a uterine biopsy can be an important tool to establish a more conclusive diagnostic in repeat breeder cows.

The presence of normal ovarian structures was confirmed in most animals by clinical $(94.4 \%)$ and postmortem examination $(94.6 \%)$. Based on that, our findings showing $2 \%$ of ovarian pathologies are in agreement with a range of variation observed in beef cattle (FARIN \& ESTILL, 1993). These results support that ovarian pathologies are not a major cause of repeat breeding in beef cows. Thus, a higher prevalence of uterine infections is expected. Regarding to the low ovarian pathologies observed in this study, it was

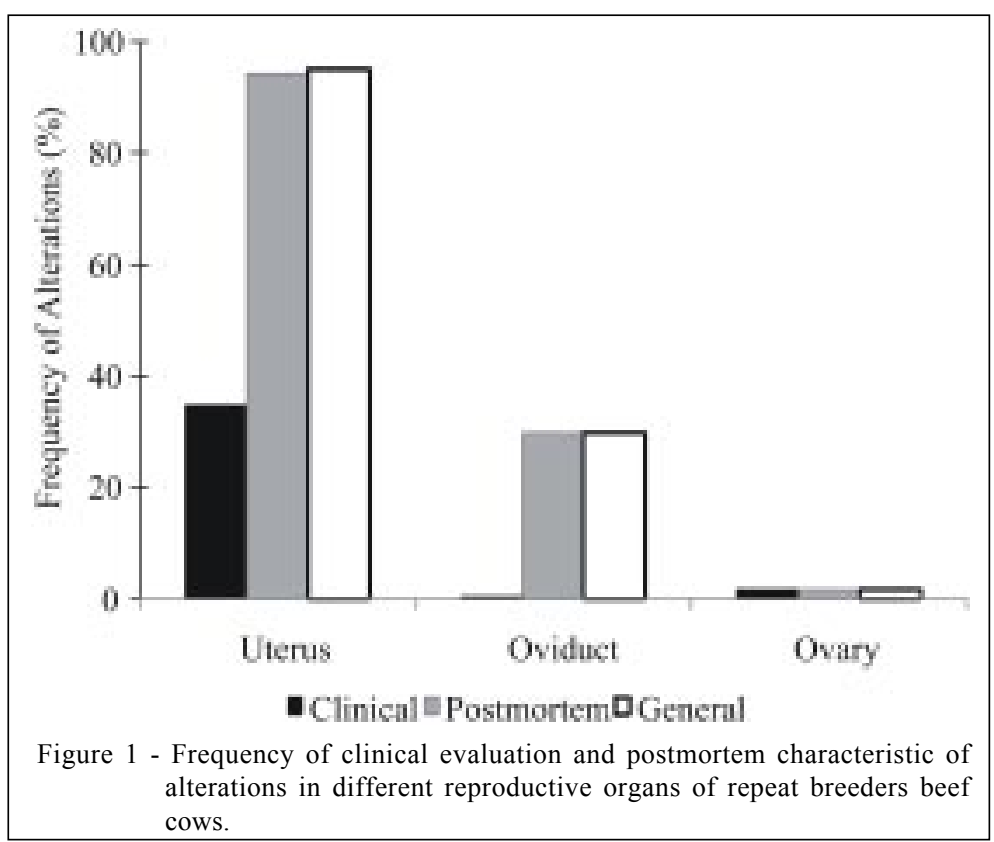

already determined that beef cattle are less susceptible to ovarian disease than dairy cattle (MORROW et al., 1966; ROBERTS, 1986).

The frequency of oviductal pathologies found in this study is higher than what was found in others showing prevalence ranging from 10 to $15 \%$ in slaughtered animals (MEGALE, 1985). KESSY \& NOAKES (1985) also studied oviduct abnormalities and diagnosed $9 \%$ oviductal lesions. In our study, working only with repeat breeder cows, we found $29.8 \%$ of the animals showing some degree of oviduct occlusion. It is worth to highlight that, besides oviductal alterations not detected by clinical examination (Table 1), they were present in a significant number of repeat breeder beef cows. The relatively high prevalence of cows with one or both oviducts altered suggests that this pathology should be considered when deciding the fate of a repeat breeder cow.

Only one chromosomal aneuploidy, a sexual pair trisomy (XXX), was observed in one out of ten (1/ 10) cows examined. Considering the samples size, this result must be examined with extreme caution. However, the presence of this animal with a chromosome anomaly and its association with infertility can not be ruled out as another cause of repeat breeding condition, even though this frequency is lower than that reported in other breeds such as the Pitangueira breed (PINHEIRO et al., 1989).

\section{CONCLUSION}

Repeat Breeder cows showed a number of uterine pathologies such as inflammatory $(42.9 \%)$ and degenerative $(59.7 \%)$ conditions. In addition, oviductal dysfunctions seem to play an important role in this syndrome. Chromosome aneuploidy should also be considered when evaluating repeat breeder cows. Our findings 
showed that clinical and more sophisticated laboratorial exams, such as uterine biopsy could help for a precise diagnosis of the causes of the repeat breeder cow syndrome. These factors should be considered carefully when farm managers must decide whether to treat or cull a repeat breeder cow.

\section{REFERENCES}

AYALON, N. A review of embryonic mortality in cattle. Journal of Reproduction and Fertility, v.54, n.2, p.483493, 1978.

BAGE, R. et al. Suprabasal progesterone levels in repeat breeder heifers during the pro- and oestrous period. Theriogenology, v.47, n.1, p.141, 1997.

BAGE, R. et al. Repeat breeding in dairy heifers: follicular dynamics and estrous cycle characteristics in relation to sexual hormone patterns. Theriogenology, v.57, n.9, p.2257-2269, 2002.

BARTLETT, P.C. et al. Repeated insemination in Michigan Holstein-Friesian cattle: Incidence, descriptive epidemiology and estimated economic impact. Theriogenology, v.26, n.3, p.309-322, 1986.

FARIN, P.W.; ESTILL, C.T. Infertility due to abnormalities of the ovaries in cattle. Veterinary Clinics of North America. Food Animal Practice, v.9. p.291-308. 1993.

GIVENS, M.D. A clinical, evidence-based approach to infectious causes of infertility in beef cattle. Theriogenology, v.66, n.3, p.648-654, 2006.

GRUNERT, E.; GREGORY, R.M. Diagnóstico e terapêutica da infertilidade na vaca. Porto Alegre: Sulina, 1984. 163p.

HANLY, S. Prenatal mortality in farm animals. Journal of Reproduction and Fertility, v.2, p.182-194, 1961.

JANG, S.S. et al. Manual of veterinary clinical bacteriology and mycology. California: University of Davis, 1976. 215p.

KATAGIRI, S.; TAKAHASHI, Y. Changes in EGF concentrations during estrous cycle in bovine endometrium and their alterations in repeat breeder cows. Theriogenology, v.62, n.1-2, p.103-112, 2004.

KESSY, B.M.; NOAKES, D.E. Uterine tube abnormalities as a cause of bovine infertility. Veterinary Record, v.117, n.6, p.122-124, 1985.
LAMMING, G.E.; DARWASH, A.O. The use of milk progesterone profiles to characterise components of subfertility in milked dairy cows. Animal Reproduction Science, v.52, n.3, p.175-190, 1998.

LUNA, L.G. Manual of histologic staining methods of the armed forces Institute of Phatology. 3.ed. New York: McGraw-Hill, 1968. 258p.

MARTINS, C.F. et al. Biópsia endometrial em vacas Bos indicus em regime extensino de criação com problemas de fertilidade. Ensaios e Ciência, v.6, n.2, p.13-33, 2002.

MEGALE, F. Anatomia e patologia do aparelho reprodutor feminino. Brasília: Curso Internacional de Transferência de Embriões. Stracta, 1985. Cap.2.

MORROW, D.A. et al. Postpartum ovarian activity and uterine involution in dairy cattle. Journal of the American Veterinary Medical Association, v.149, p.1596-1609, 1966.

NEVES, J.P. Características clínicas, bacteriológicas e histopatológicas de endometrites pós-puerperais em bovinos. 1976. 50f. Dissertação de Mestrado - Curso de Pósgraduação em Medicina Veterinária, Universidade Federal de Santa Maria.

PINHEIRO, L.E.L. et al. Freqüencia de anomalias cromossômicas em fêmeas bovinas de diferentes raças com distúrbios de fertilidade. Revista Brasileira de Reprodução Animal, v.13, n.4, p.221-228, 1989.

ROBERTS, S.J. Veterinary obstetrics and genital diseases (Theriogenology). Ann Arbor: Edwards Brothers, 1986. 981p.

SHORT, R.E. et al. Physiological mechanisms controlling anestrus and infertility in postpartum beef cattle. Journal of Animal Science, v.68, n.3, p.799-816, 1990.

STUDER, E.; MORROW, D.A. Postpartum evaluation of bovine reproductive potential: comparison of findings from genital tract examination per rectum, uterine culture, and endometrial biopsy. Journal of the American Veterinary Medical Association, v.172, n.4, p.489-494, 1978.

WILLIAMS, E.J. et al. Clinical evaluation of postpartum vaginal mucus reflects uterine bacterial infection and the immune response in cattle. Theriogenology, v.63, n.1, p.102-117, 2005.

ZEMJANIS, R. Repeat-breeding or conception failure in cattle. In. MORROW, D.A. Current therapy in theriogenology. Philadelphia: Saunders, 1980. Cap.5, p.205-213. 